\title{
Analisis Quality of Service (QoS) Jaringan Telekomunikasi High-Speed Downlink Packet Access (HSDPA) pada Teknologi 3.5G
}

\author{
Mey Fenny Wati Simanjuntak, Oky Dwi Nurhayati, Eko Didik Widianto \\ Program Studi Sistem Komputer Fakultas Teknik Universitas Diponegoro \\ Jalan Prof. Sudharto, Tembalang, Semarang, Indonesia \\ simanjuntak.fenny@gmail.com
}

\begin{abstract}
Abstrak - Sejak layanan teknologi $3 G$ pertama kali diperkenalkan, permintaan akan layanan berbasis paket data dari tahun ke tahun mengalami peningkatan yang pesat. Menanggapi hal tersebut, para penyedian jaringan telekomunikasi terus berusaha untuk meningkatkan kemampuan jaringannya. Salah satu solusinya menerapkan teknologi High-Speed Downlink Packet Access yang direkomendasikan oleh 3GPP Release 5. Penelitian ini dikhususkan untuk menganalisis Quality of Service jaringan telekomunikasi High-Speed Downlink Packet Access di Kecamatan Tembalang Kota Semarang. Analisis Quality of Service jaringan telekomunikasi High-Speed Downlink Packet Access pada penelitian ini bertujuan untuk memberikan gambaran kualitas jaringan telekomunikasi High-Speed Downlink Packet Access dari sisi bandwidth, throughput, packet loss dan delay. Metode penelitian yang dibahas dalam penelitian ini yaitu penelitian kualitatif observatif, dimana akan dilakukan pengamatan tentang bagaimana QoS jaringan telekomunikasi High-Speed Downlink Packet Access pada teknologi 3.5G di Kecamatan Tembalang Kota Semarang. Proses pengamatan dalam menganalisis Quality of Service jaringan telekomunikasi High-Speed Downlink Packet Access di Kecamatan Tembalang Kota Semarang berdasarkan 4 parameter diantaranya bandwidth, throughput, packet loss dan delay. Aplikasi yang digunakan yaitu monitoring application Elnus Bandwidth Meter dan Axence NetTools Professional 4.0. Selain itu, Quality of Service jaringan telekomunikasi HighSpeed Downlink Packet Access di Kecamatan Tembalang Kota Semarang diamati berdasarkan waktu yaitu harian, mingguan dan bulanan.
\end{abstract}

Kata Kunci : Teknologi 3.5G, High-Speed Downlink Packet Access, Quality of Service, Elnus Bandwidth Meter dan Axence NetTools Professional 4.0

\section{PENDAHULUAN}

EJAK layanan teknologi $3 \mathrm{G}$ pertama kali diperkenalkan, C permintaan akan layanan berbasis paket data dari tahun ke tahun mengalami peningkatan yang pesat. Menanggapi hal tersebut, para penyedia jaringan telekomunikasi terus berusaha untuk meningkatkan kemampuan pada jaringannya. Salah satu solusinya dengan menerapkan teknologi HSDPA yang direkomendasikan oleh 3GPP Release $5^{[1]}$.

HSDPA merupakan teknologi 3.5G. HSDPA adalah pengembangan dari jaringan WCDMA yang merupakan teknologi generasi 3G, seperti halnya CDMA 2000 yang telah dikembangkan menjadi EV-DO. HSDPA mempunyai layanan berbasis paket data dengan data rate mencapai $14.4 \mathrm{Mbps}$ dan bandwitdh 5 Mhz pada WCDMA downlink ${ }^{[2]}$.

Jaringan telekomunikasi HSDPA memberi berbagai aplikasi layanan antara lain layanan data (browsing), live streaming seperti video call, berita dan mobile-TV. Jaringan telekomunikasi HSDPA juga memberikan kemudahan kepada pengguna untuk menikmati layanan audio-visual secara real time. Perbedaan jaringan telekomunikasi HSDPA dengan jaringan telekomunikasi sebelumnya yakni WCDMA dapat dilihat dari QoS ${ }^{[1]}$.

QoS merupakan kemampuan suatu jaringan untuk menyediakan layanan yang baik dengan menyediakan bandwidth, mengatasi jitter dan delay. Tujuan QoS adalah untuk menyediakan kualitas layanan yang berbeda-beda untuk beragam kebutuhan akan layanan di dalam jaringan IP, sebagai contoh untuk menyediakan bandwidth, menurunkan hilangnya paket-paket, menurunkan waktu tunda dan variasi waktu tunda di dalam proses transmisinya ${ }^{[20]}$

Analisis Quality of Service jaringan telekomunikasi HSDPA pada teknologi $3.5 \mathrm{G}$ untuk Tugas Akhir ini menggunakan monitoring application Elnus Bandwidth Meter dan Axence NetTools Professional 4.0. Analisis QoS ini diharapkan dapat memberikan gambaran kualitas jaringan telekomunikasi HSDPA dari sisi bandwidth, throughput, packet loss dan delay.

Penelitian ini didorong oleh hasil penelitian yang sebelumnya pernah dilakukan. Penelitian dari Fanny Nurindra Permana yang dipublikasikan di Jurnal Teknik POMITS Institut Teknologi Sepuluh Nopember pada tahun 2012. Penelitian ini membahas bagaimana menganalisa kinerja MPEG-4 video streaming pada jaringan HSDPA dengan parameter throughput, packet loss, delay dan evaluasi kualitas video. Kesimpulan dari penelitian ini adalah performa video streaming melalui jaringan HSDPA dipengaruhi oleh banyaknya jumlah user yang terhubung dalam satu base station, pergerakan user dan jarak terhadap base station turut berpengaruh pada performa layanan video streaming yang diperoleh ${ }^{[11]}$.

Penelitian dari Agus Stiawansyah yang dipublikasikan di Skripsi Program Studi Teknik Informatika Universitas Bina Dharma Palembang pada tahun 2012. Penelitian ini membahas bagaimana pengembangan menganalisa kinerja jaringan pusat Internet pedesaan berbasis VSAT di Kabupaten Muara Enim dengan parameter bandwidth, throughput, delay dan packet loss. Kesimpulan dari penelitian ini adalah berdasarkan standarisasi TIPHON besar Packet loss untuk, Kecamatan Ujan Mas, Kecamatan Talang Ubi, Kecamatan Penukal kategori degradasi sedang, dan Kecamatan Penukal Abab termasuk kategori jelek, sedangkan untuk Kecamatan Rambang Dangku termasuk kategori degradasi bagus ${ }^{[17]}$.

Perbedaan kedua penelitian tersebut dengan penelitian ini adalah membahas bagaimana menganalisis QoS jaringan telekomunikasi HSDPA dengan parameter bandwidth, throughput, packet loss dan delay di Kecamatan Tembalang Kota Semarang dalam jangkauan waktu harian, mingguan dan bulanan. Kesimpulan dari penelitian ini adalah didapatkan 16 (e-ISSN: 2338-0403) a JTsiskom-67 
waktu, hari dan minggu dengan trafik tinggi dan rendah di masing-masing parameter.

\section{METODOLOGI PENELITIAN}

Penelitian dilakukan di Kecamatan Tembalang karena Kecamatan Tembalang memiliki jumlah penduduk 147.564 jiwa. Kecamatan Tembalang memiliki jumlah penduduk terbanyak ketiga di Kota Semarang ${ }^{[10]}$. Selain itu, Kecamatan Tembalang merupakan salah satu pusat pendidikan di Kota Semarang misalnya Universitas Diponegoro, Politeknik Negeri Semarang, Universitas Pandanaran, dan Politeknik Kesehatan Kementerian Kesehatan Semarang dan lain-lain.

Penelitian ini menggunakan provider 3 (three) dengan pertimbangan banyaknya pengguna provider 3 di Kecamatan Tembalang. Selain itu, provider 3 menawarkan paket-paket Internet dengan kuota yang besar dan harga masih terjangkau bagi penduduk Kecamatan Tembalang terutama mahasiswa. Dalam pembuatan tugas akhir ini pembahasan masalah memiliki batasan pada permasalahan antara lain jaringan telekomunikasi HSDPA pada teknologi $3.5 \mathrm{G}$, parameter yang dianalisis adalah bandwidth, throughput, packet loss dan delay, monitoring application menggunakan Elnus Bandwidth Meter untuk pengukuran parameter bandwidth dan throughput, sedangkan Axence NetTools Professional 4.0 untuk pengukuran parameter packet loss dan delay, provider yang digunakan adalah 3 (three), pengujian dilakukan di Kecamatan Tembalang Kota Semarang dan pengujian dilakukan mulai tanggal 10 Mei 2015 sampai dengan tanggal 6 Juni 2015.

Tabel 1 menunjukkan kategori throughput.

Tabel 1 Standarisasi Throughput menurut TIPHON ${ }^{[18]}$

\begin{tabular}{|c|c|}
\hline $\begin{array}{c}\text { Kategori } \\
\text { Throughput }\end{array}$ & Throughput \\
\hline Buruk & $0-338 \mathrm{kbps}$ \\
\hline Cukup Baik & $338-700 \mathrm{kbps}$ \\
\hline Baik & $700-1200 \mathrm{kbps}$ \\
\hline Lebih Baik & $1200 \mathrm{kbps}-2.1 \mathrm{Mbps}$ \\
\hline Terbaik & $>2.1 \mathrm{Mbps}$ \\
\hline
\end{tabular}

Tabel 2 menunjukkan kategori packet loss.

Tabel 2 Standarisasi Packet loss menurut TIPHON ${ }^{[19]}$

\begin{tabular}{|} 
Tabel 2 Standarisasi Packet loss menurut TIPHON \\
$\begin{array}{c}\text { Kategori } \\
\text { Degradasi }\end{array}$ & Packet loss \\
\hline Sangat Bagus & $0-2 \%$ \\
\hline Bagus & $3-14 \%$ \\
\hline Sedang & $15-24 \%$ \\
\hline Jelek & $>25 \%$ \\
\hline
\end{tabular}

Tabel 3 menunjukkan kategori delay.

Tabel 3 Standarisasi Delay menurut TIPHON ${ }^{[19]}$
\begin{tabular}{|c|c|}
\hline Kategori Delay & Besar Delay \\
\hline Sangat Bagus & $<150 \mathrm{~ms}$ \\
\hline Bagus & $150 \mathrm{~s} / \mathrm{d} 300 \mathrm{~ms}$ \\
\hline Sedang & $300 \mathrm{~s} / \mathrm{d} 450 \mathrm{~ms}$ \\
\hline Jelek & $>450 \mathrm{~ms}$ \\
\hline
\end{tabular}

Objek yang digunakan dalam penelitian ini adalah QoS seperti bandwidth, throughput, packet loss, dan delay jaringan telekomunikasi HSDPA di Kecamatan Tembalang Kota Semarang dalam jangkauan waktu harian, mingguan dan bulanan.

Pada tahap penelitian berisi kerangka pemecahan masalah, sehingga dalam pemecahan masalah dapat dilakukan dengan mudah. Pada penelitian ini ada beberapa tahap yang perlu dilakukan sehingga akan lebih mudah dalam mengumpulkan data yang diperlukan antara lain membuat rencana tindakan (action planning), melakukan pengujian serta mengumpulan data hasil pengujian (action taking), analisis dan kesimpulan.

Pada penelitian ini terdapat langkah-langkah untuk mendapatkan kualitas layanan jaringan telekomunikasi HSDPA dengan parameter bandwidth, throughput, packet loss dan delay. Pengukuran parameter dilakukan pada siang hari antara pukul 11.00-14.00 WIB dan sore hari antara pukul 15.00-18.00 WIB. Flowchart analisis QoS jaringan telekomunikasi HSDPA dapat dilihat pada Gambar 1.

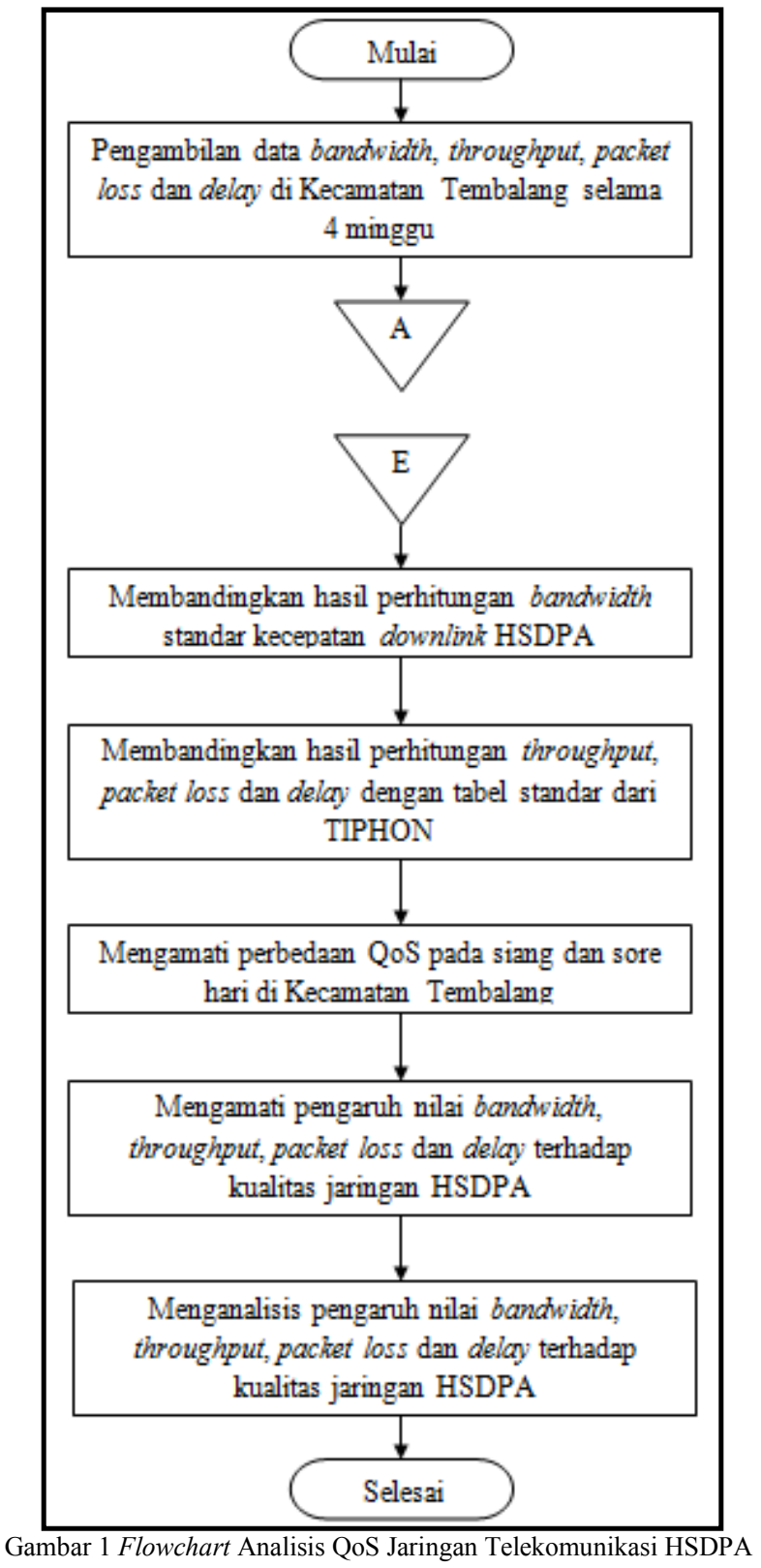

Pada penelitian ini digunakan monitoring application Elnus Bandwidth Meter untuk mendapatkan nilai bandwidth untuk jaringan telekomunikasi HSDPA di Kecamatan Tembalang 
Kota Semarang dalam satuan kbps (kilo bit per second). Gambar 2 merupakan flowchart pengukuran bandwidth.

Penelitian ini menggunakan monitoring application Elnus Bandwidth Meter untuk mendapatkan nilai throughput untuk jaringan telekomunikasi HSDPA di Kecamatan Tembalang Kota Semarang dalam satuan bps (bit per second). Gambar 3 merupakan flowchart pengukuran throughput.

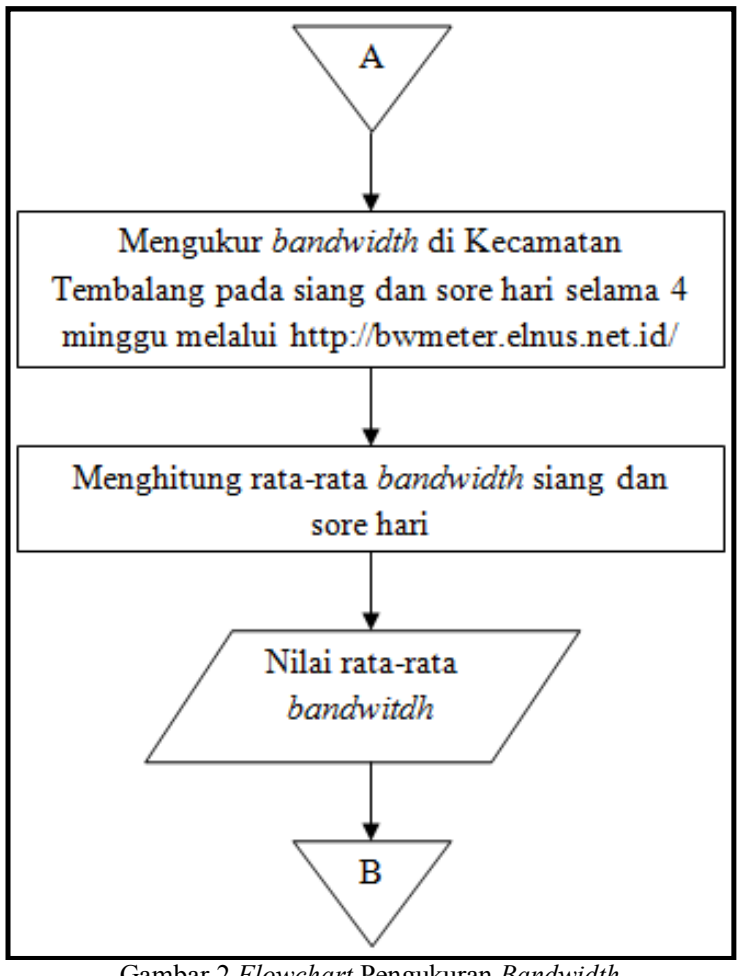

Gambar 2 Flowchart Pengukuran Bandwidth

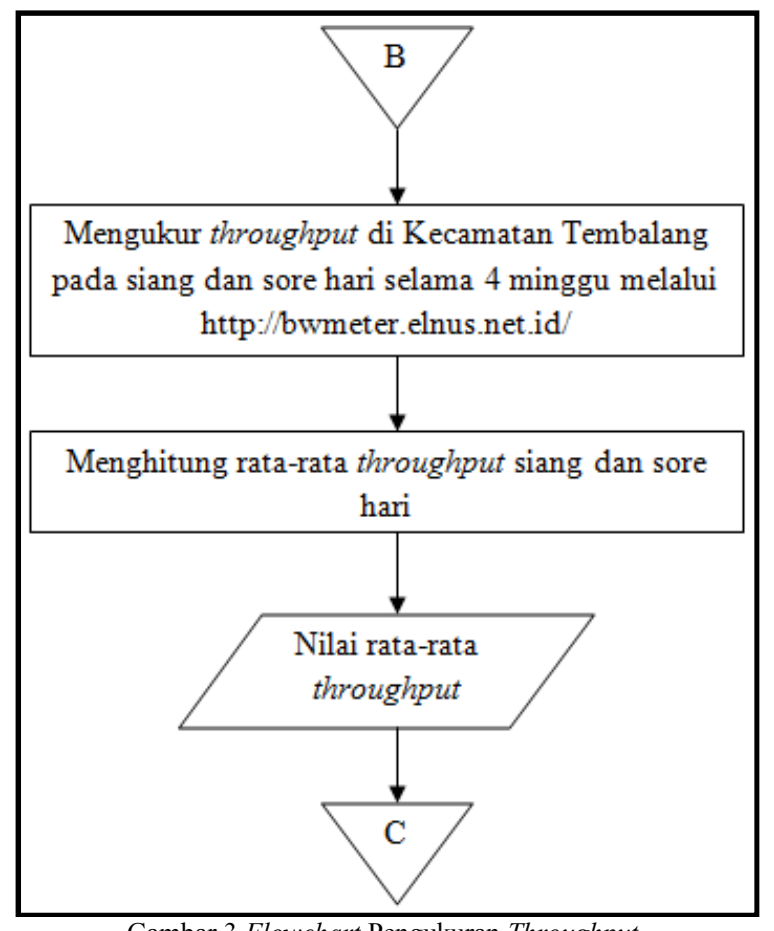

Gambar 3 Flowchart Pengukuran Throughput

Penelitian ini menggunakan monitoring application Axence NetTools Professional 4.0 dengan fitur tool Netwatch untuk mendapatkan nilai packet loss untuk jaringan telekomunikasi HSDPA di Kecamatan Tembalang Kota Semarang dalam hitungan persentase (\%). Nilai parameter packet loss diperoleh dengan mengelola packets yang terdiri dari sent, lost dan \%lost. Gambar 4 merupakan flowchart pengukuran packet loss.

Penelitian ini menggunakan monitoring application Axence NetTools Professional 4.0 dengan fitur tool Netwatch untuk mendapatkan nilai delay untuk jaringan telekomunikasi HSDPA di Kecamatan Tembalang Kota Semarang dalam satuan millisecond (ms). Nilai parameter delay diperoleh dengan mengelola response time yang terdiri dari average, minimum dan maximum. Gambar 5 merupakan flowchart pengukuran delay.
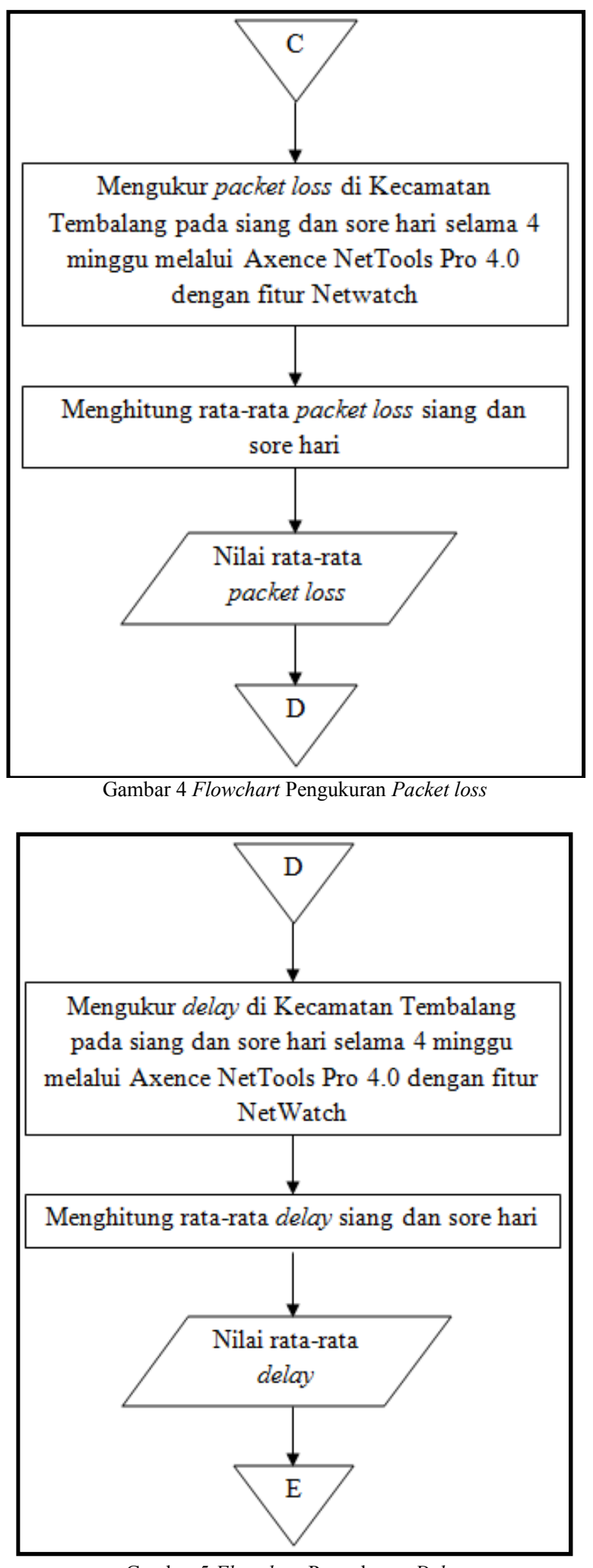

Gambar 5 Flowchart Pengukuran Delay 
III. HASIL PENELITIAN DAN PEMBAHASAN

Berdasarkan hasil pengukuran jaringan telekomunikasi HSDPA di Kecamatan Tembalang Kota Semarang yang dilakukan mulai tanggal 10-05-2015 sampai dengan 06-062015 didapat grafik hasil pengukuran bandwidth minggu I dapat dilihat pada Gambar 6 .

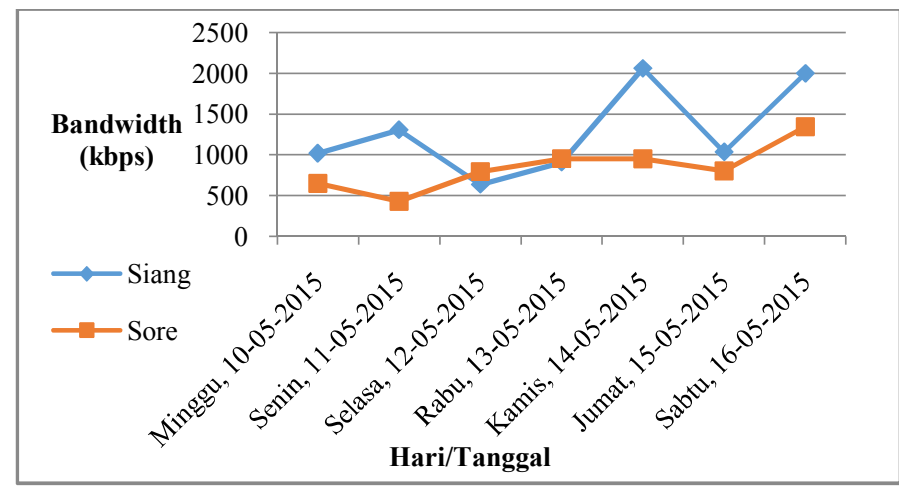

Gambar 6 Grafik Hasil Pengukuran Bandwidth Minggu I

Berdasarkan Gambar 6, hasil pengukuran bandwidth minggu I di Kecamatan Tembalang Kota Semarang diperoleh bandwidth yang paling besar pada saat siang hari dan paling kecil pada saat sore hari. Pengukuran bandwidth yang dilakukan mulai tanggal 10-05-2015 sampai dengan 16-052015 diperoleh trafik paling tinggi pada hari Sabtu tanggal 1605-2015 dan trafik paling rendah pada hari Selasa tanggal 1205-2015. Grafik hasil pengukuran bandwidth minggu II dapat dilihat pada Gambar 4.2. Grafik hasil pengukuran bandwidth minggu II dapat dilihat pada Gambar 7.

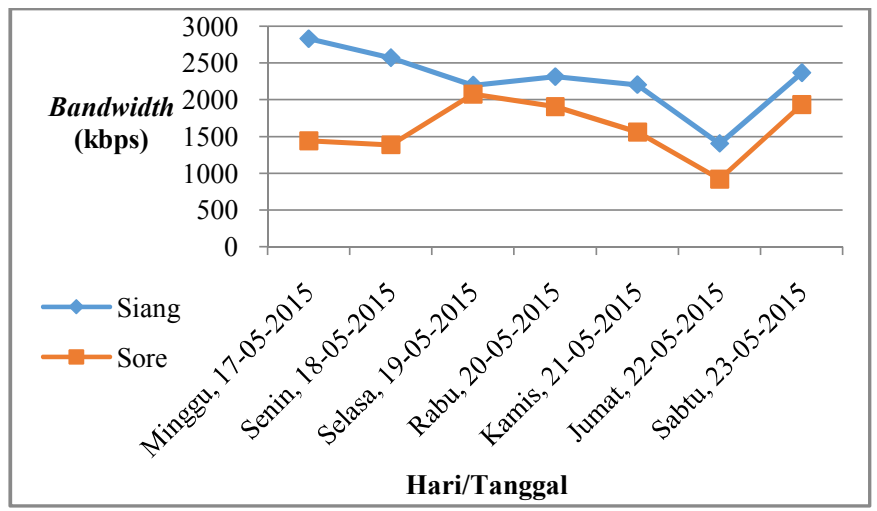

Gambar 7 Grafik Hasil Pengukuran Bandwidth Minggu II

Berdasarkan Gambar 7, hasil pengukuran bandwidth minggu II di Kecamatan Tembalang Kota Semarang diperoleh bandwidth yang paling besar pada saat siang hari dan paling kecil pada saat sore hari. Pengukuran bandwidth yang dilakukan mulai tanggal 17-05-2015 sampai dengan 23-052015 diperoleh trafik paling tinggi pada hari Sabtu tanggal 2305-2015 dan trafik paling rendah pada hari Jumat tanggal 2205-2015. Grafik hasil pengukuran bandwidth minggu III dapat dilihat pada Gambar 8 .

Berdasarkan Gambar 8, hasil pengukuran bandwidth minggu III di Kecamatan Tembalang Kota Semarang diperoleh bandwidth yang paling besar pada saat siang hari dan paling kecil pada saat sore hari. Pengukuran bandwidth yang dilakukan mulai tanggal 24-05-2015 sampai dengan 30-052015 diperoleh trafik paling tinggi pada hari Rabu tanggal $27-$ 05-2015 dan trafik paling rendah pada hari Minggu tanggal 2405-2015. Grafik hasil pengukuran bandwidth minggu IV dapat dilihat pada Gambar 9.

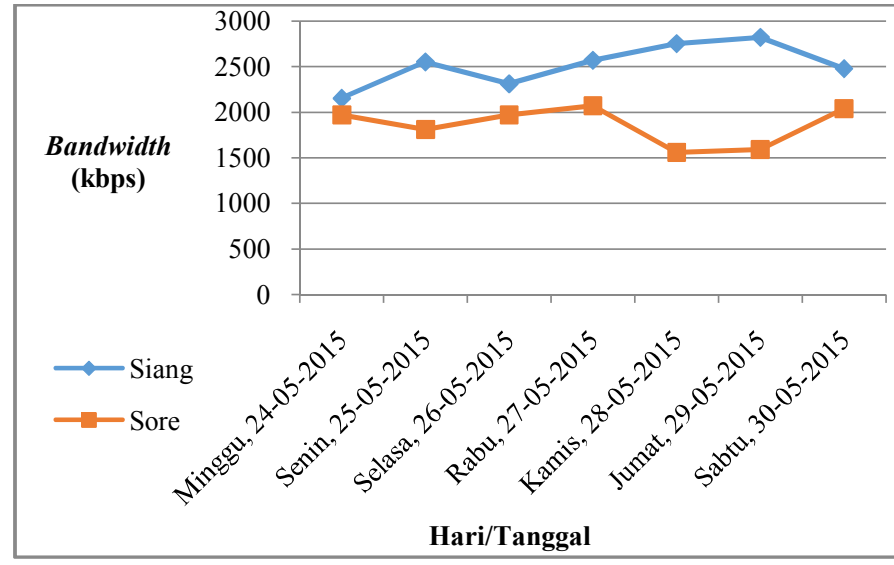

Gambar 8 Grafik Hasil Pengukuran Bandwidth Minggu III

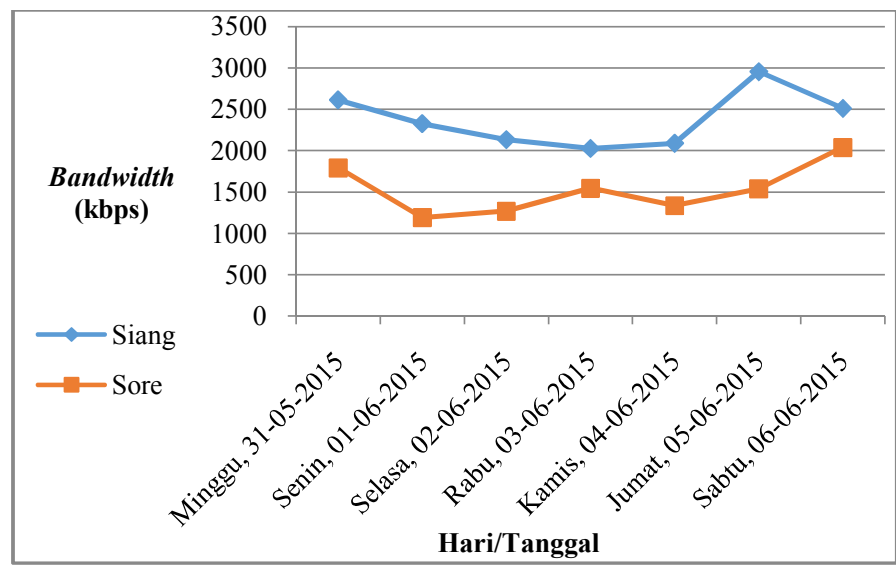

Gambar 9 Grafik Hasil Pengukuran Bandwidth Minggu IV

Berdasarkan Gambar 9, hasil pengukuran bandwidth minggu IV di Kecamatan Tembalang Kota Semarang diperoleh bandwidth yang paling besar pada saat siang hari dan paling kecil pada saat sore hari. Pengukuran bandwidth yang dilakukan mulai tanggal 31-05-2015 sampai dengan 06-062015 diperoleh trafik paling tinggi pada hari Sabtu tanggal 0606-2015 dan trafik paling rendah pada hari Selasa tanggal 0206-2015. Grafik hasil pengukuran bandwidth 1 bulan dapat dilihat pada Gambar 10 .

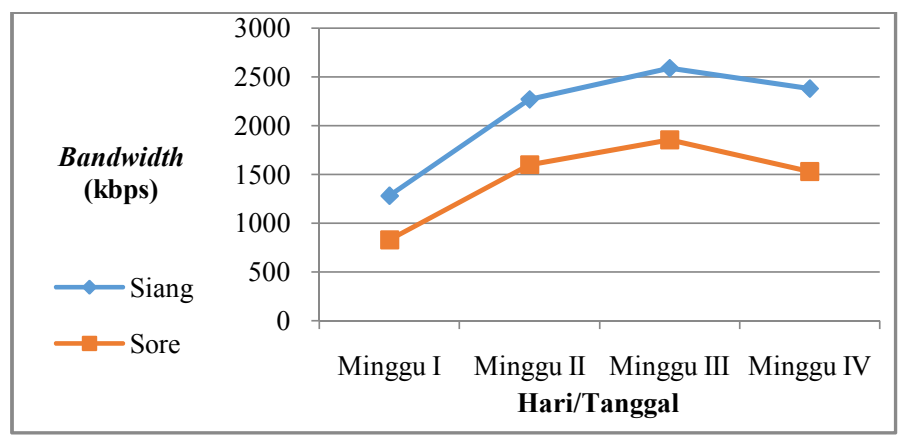

Gambar 10 Grafik Hasil Pengukuran Bandwidth 1 Bulan

Gambar 10 menunjukkan hasil rekapitulasi pengukuran bandwidth dalam hitungan bulan. Berdasarkan rekapitulasi bulanan tersebut, diperoleh kesimpulan hasil pengukuran bandwidth yang paling besar terjadi pada minggu III. Sedangkan untuk hasil pengukuran bandwidth yang paling kecil terjadi pada minggu I.

Berdasarkan teori, HSDPA mendukung kecepatan downlink sebesar 1.8 Mbps, 3.6 Mbps, 7.2 Mbps dan 14.4 Mbps. Tabel hasil bandwidth di Kecamatan Tembalang dapat dilihat pada Tabel 4. 
Tabel 4 Hasil Bandwidth di Kecamatan Tembalang

\begin{tabular}{|c|c|c|}
\hline Minggu & \multicolumn{2}{|c|}{$\begin{array}{c}\text { Bandwidth (kbps) } \\
\text { Siang }\end{array}$} \\
\hline More \\
\hline Minggu I & 1281 & 830 \\
\hline Minggu II & 2270 & 1602 \\
\hline Minggu IV & 2519 & 1857 \\
\hline
\end{tabular}

Tabel 4 menunjukkan hasil rekapitulasi pengukuran bandwidth dalam hitungan bulan. Berdasarkan rekapitulasi bulanan tersebut, diperoleh kesimpulan hasil pengukuran bandwidth yang didapat pada siang dan sore hari untuk minggu I belum mendukung kecepatan downlink HSDPA karena besar nilai bandwidth siang adalah $1.25 \mathrm{Mbps}$ dan bandwidth sore $0.81 \mathrm{Mbps}$. Hasil pengukuran bandwidth yang didapat pada sore hari untuk minggu II belum mendukung kecepatan downlink HSDPA karena besar nilai bandwidth sore adalah $1.56 \mathrm{Mbps}$. Hasil pengukuran bandwidth yang didapat pada sore hari untuk minggu IV belum mendukung kecepatan downlink HSDPA karena besar nilai bandwidth sore adalah $1.49 \mathrm{Mbps}$.

Berdasarkan hasil pengukuran jaringan telekomunikasi HSDPA di Kecamatan Tembalang Kota Semarang yang dilakukan mulai tanggal 10-05-2015 sampai dengan 06-062015 didapat grafik hasil pengukuran throughput minggu I dapat dilihat pada Gambar 11.

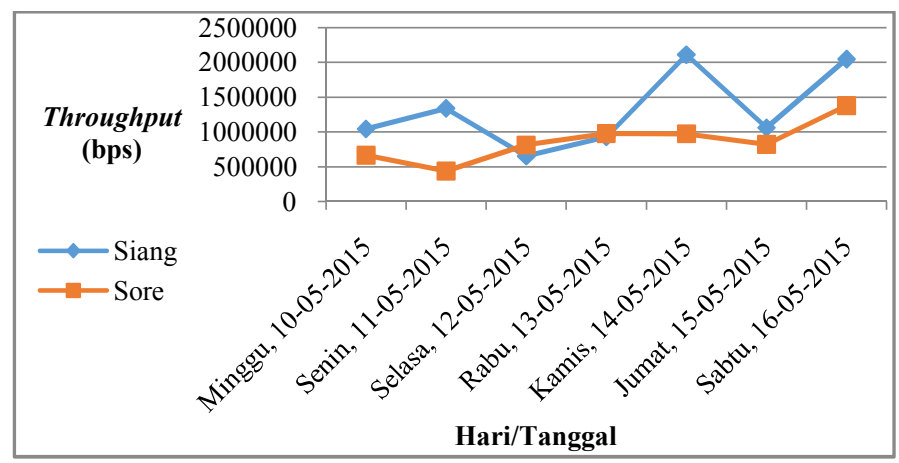

Gambar 11 Grafik Hasil Pengukuran Throughput Minggu I

Berdasarkan Gambar 11, hasil pengukuran throughput minggu I di Kecamatan Tembalang Kota Semarang diperoleh throughput yang paling besar pada saat siang hari dan paling kecil pada saat sore hari. Pengukuran throughput yang dilakukan mulai tanggal 10-05-2015 sampai dengan 16-052015 diperoleh trafik paling tinggi pada hari Sabtu tanggal 1605-2015 dan trafik paling rendah pada hari Selasa tanggal 1205-2015. Grafik hasil pengukuran throughput minggu II dapat dilihat pada Gambar 12 .

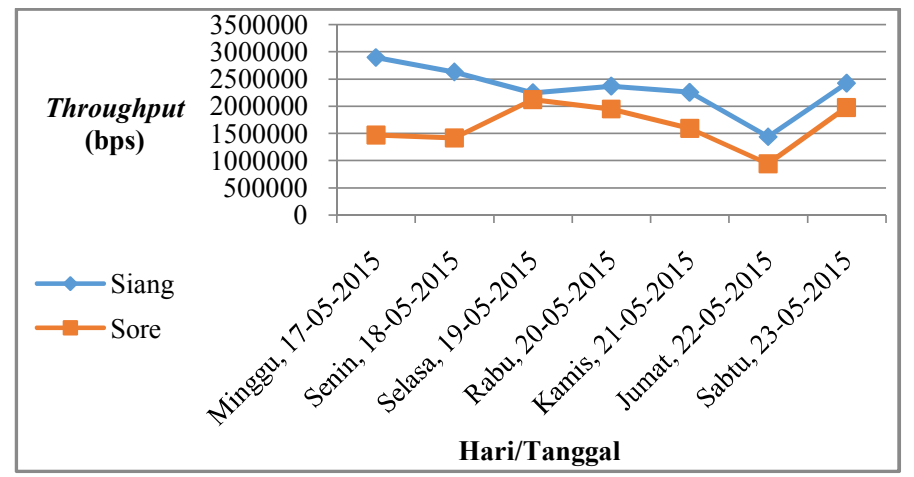

Gambar 12 Grafik Hasil Pengukuran Throughput Minggu II
Berdasarkan Gambar 12, hasil pengukuran throughput minggu II di Kecamatan Tembalang Kota Semarang diperoleh throughput yang paling besar pada saat siang hari dan paling kecil pada saat sore hari. Pengukuran throughput yang dilakukan mulai tanggal 17-05-2015 sampai dengan 23-052015 diperoleh trafik paling tinggi pada hari Sabtu tanggal 2305-2015 dan trafik paling rendah pada hari Jumat tanggal 2205-2015. Grafik hasil pengukuran throughput minggu III dapat dilihat pada Gambar 13 .

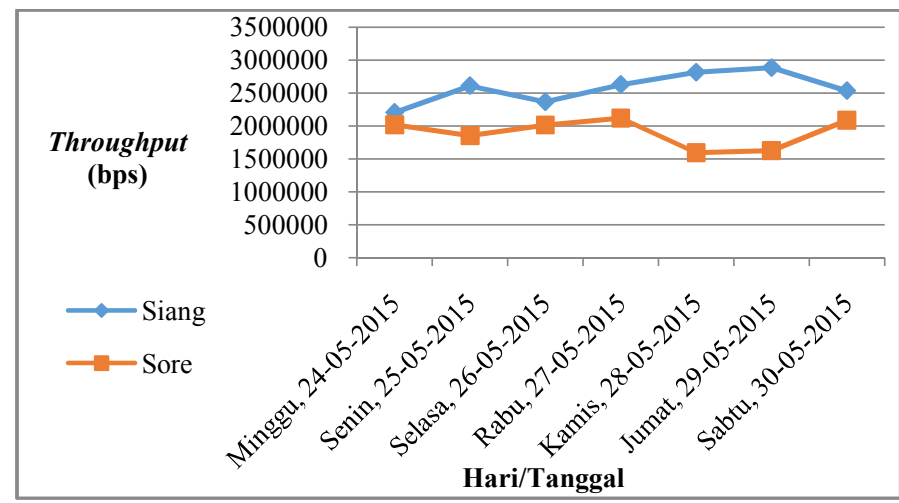

Gambar 13 Grafik Hasil Pengukuran Throughput Minggu III

Berdasarkan Gambar 13, hasil pengukuran throughput minggu III di Kecamatan Tembalang Kota Semarang diperoleh throughput yang paling besar pada saat siang hari dan paling kecil pada saat sore hari. Pengukuran throughput yang dilakukan mulai tanggal 24-05-2015 sampai dengan 30-052015 diperoleh trafik paling tinggi pada hari Rabu tanggal 2705-2015 dan trafik paling rendah pada hari Minggu tanggal 2405-2015. Grafik hasil pengukuran throughput minggu IV dapat dilihat pada Gambar 14.

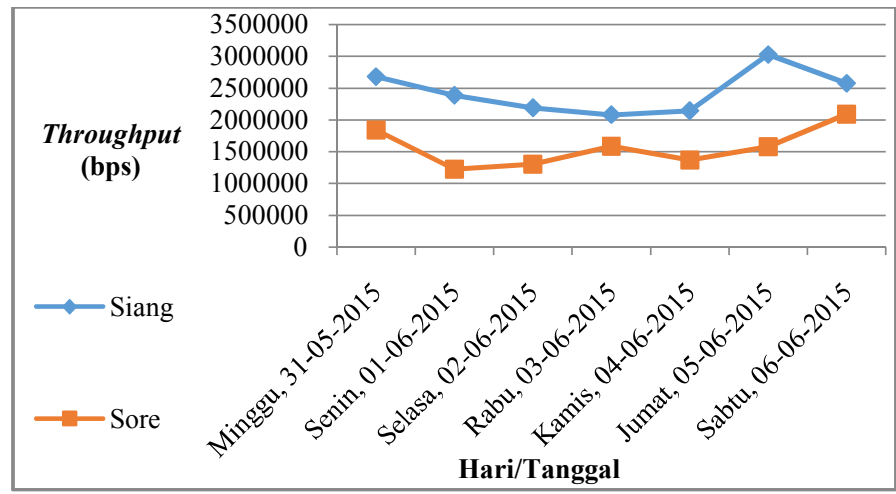

Gambar 14 Grafik Hasil Pengukuran Throughput Minggu IV

Berdasarkan Gambar 14, hasil pengukuran throughput minggu IV di Kecamatan Tembalang Kota Semarang diperoleh throughput yang paling besar pada saat siang hari dan paling kecil pada saat sore hari. Pengukuran throughput yang dilakukan mulai tanggal 31-05-2015 sampai dengan 06-062015 diperoleh trafik paling tinggi pada hari Sabtu tanggal 0606-2015 dan trafik paling rendah pada hari Selasa tanggal 0206-2015.

Gambar 15 menunjukkan hasil rekapitulasi pengukuran throughput dalam hitungan bulan. Berdasarkan rekapitulasi bulanan tersebut, diperoleh kesimpulan hasil pengukuran throughput yang paling besar terjadi pada minggu III. Sedangkan untuk hasil pengukuran throughput yang paling kecil terjadi pada minggu I. Grafik hasil pengukuran throughput 1 bulan dapat dilihat pada Gambar 15. 


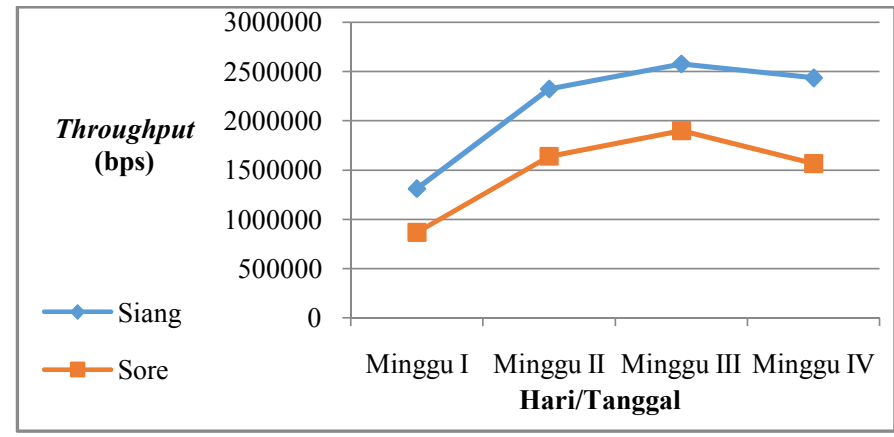

Gambar 15 Grafik Hasil Pengukuran Throughput 1 Bulan

Berdasarkan standarisasi TIPHON, untuk kategori throughput terbaik jika $>2.1 \mathrm{Mbps}$, lebih baik jika $1200 \mathrm{kbps}-$ 2.1 Mbps, baik jika 700-1200 kbps, cukup baik jika 338-700 kbps dan kategori buruk jika 0-338 kbps. Tabel hasil throughput siang hari di Kecamatan Tembalang dapat dilihat pada Tabel 5.

Tabel 5 Hasil Throughput Siang Hari di Kecamatan Tembalang

\begin{tabular}{|l|c|c|c|}
\hline Minggu & $\begin{array}{c}\text { Rata-rata } \\
\text { Throughput } \\
\text { (bps) }\end{array}$ & $\begin{array}{c}\text { Rata-rata } \\
\text { Throughput } \\
\text { (kbps) }\end{array}$ & TIPHON \\
\hline Minggu I & 1311995.6 & 1281 & Lebih Baik \\
\hline Minggu II & 2324819.4 & 2270 & Terbaik \\
\hline Minggu III & 2579777.8 & 2519 & Terbaik \\
\hline Minggu IV & 2437833.9 & 2381 & Terbaik \\
\hline
\end{tabular}

Berdasarkan rekapitulasi bulanan tersebut, diperoleh kesimpulan hasil pengukuran throughput siang hari minggu I termasuk kategori lebih baik karena besar nilai throughput antara 1200 kbps sampai 2.1 Mbps. Sedangkan hasil pengukuran throughput siang hari minggu II, III dan IV termasuk kategori terbaik karena besar nilai throughput $>2.1$ Mbps. Tabel hasil throughput sore hari di Kecamatan Tembalang dapat dilihat pada Tabel 6 .

Tabel 6 Hasil Throughput Sore Hari di Kecamatan Tembalang

\begin{tabular}{|l|c|c|c|}
\hline Minggu & $\begin{array}{c}\text { Rata-rata } \\
\text { Throughput } \\
\text { (bps) }\end{array}$ & $\begin{array}{c}\text { Rata-rata } \\
\text { Throughput } \\
\text { (kbps) }\end{array}$ & TIPHON \\
\hline Minggu I & 868410.51 & 848 & Baik \\
\hline Minggu II & 1640799.08 & 1602 & Lebih Baik \\
\hline Minggu III & 1901854.72 & 1857 & Lebih Baik \\
\hline Minggu IV & 156819.56 & 1531 & Lebih Baik \\
\hline
\end{tabular}

Tabel 6 menunjukan hasil rekapitulasi pengukuran throughput sore hari dalam hitungan bulan. Berdasarkan rekapitulasi bulanan tersebut, diperoleh kesimpulan hasil pengukuran throughput sore hari minggu I termasuk kategori baik karena besar nilai throughput antara 700 sampai 1200 kbps. Sedangkan hasil pengukuran throughput sore hari minggu II, III dan IV termasuk kategori lebih baik karena besar nilai throughput antara $1200 \mathrm{kbps}$ sampai $2.1 \mathrm{Mbps}$.

Berdasarkan hasil pengukuran jaringan telekomunikasi HSDPA di Kecamatan Tembalang Kota Semarang yang dilakukan mulai tanggal 10-05-2015 sampai dengan 06-062015 didapat grafik hasil pengukuran packet loss minggu I dapat dilihat pada Gambar 16.

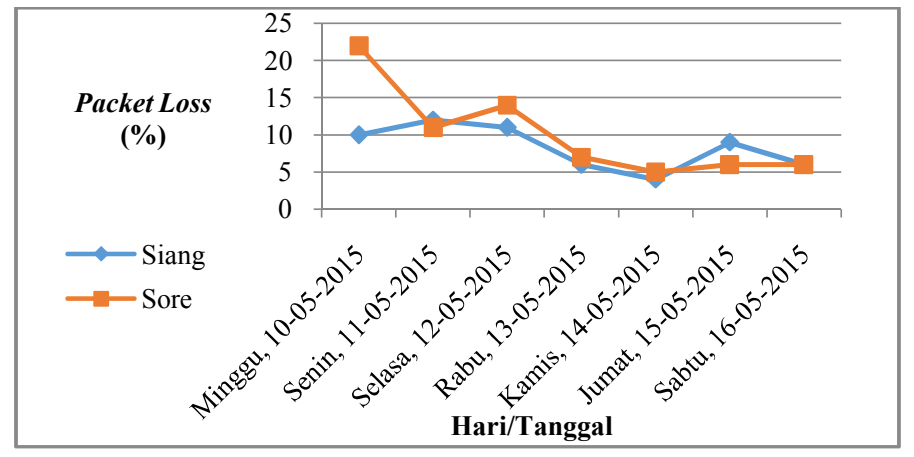

Gambar 16 Grafik Hasil Pengukuran Packet loss Minggu I

Berdasarkan Gambar 16, hasil pengukuran packet loss minggu I di Kecamatan Tembalang Kota Semarang diperoleh packet loss yang paling kecil pada saat siang hari dan paling besar pada saat sore hari. Pengukuran packet loss yang dilakukan mulai tanggal 10-05-2015 sampai dengan 16-052015 diperoleh trafik paling rendah pada hari Sabtu tanggal 1605-2015 dan trafik paling tinggi pada hari Minggu tanggal 1005-2015. Grafik hasil pengukuran packet loss minggu II dapat dilihat pada Gambar 17.

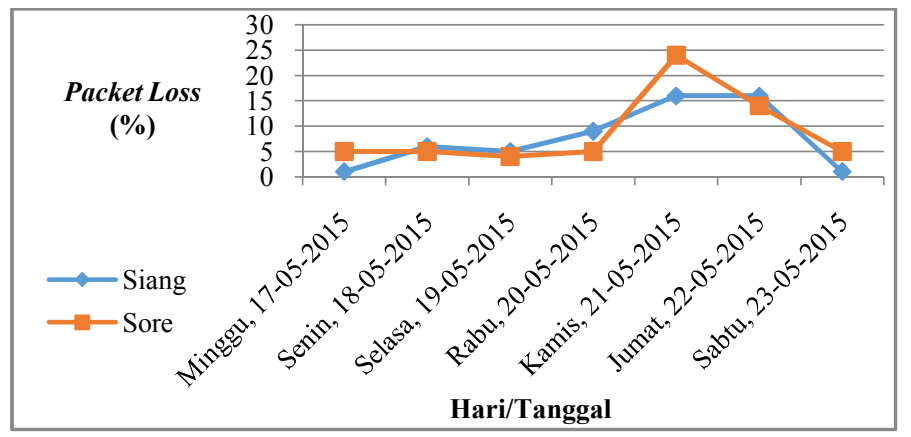

Gambar 17 Grafik Hasil Pengukuran Packet loss Minggu II

Berdasarkan Gambar 17, hasil pengukuran packet loss minggu II di Kecamatan Tembalang Kota Semarang diperoleh packet loss yang paling kecil pada saat siang hari dan paling besar pada saat sore hari. Pengukuran packet loss yang dilakukan mulai tanggal 17-05-2015 sampai dengan 23-052015 diperoleh trafik paling rendah pada hari Minggu tanggal 17-05-2015, hari Sabtu tanggal 23-05-2015 dan trafik paling tinggi pada hari Kamis tanggal 21-05-2015. Grafik hasil pengukuran packet loss minggu III dapat dilihat pada Gambar 18.

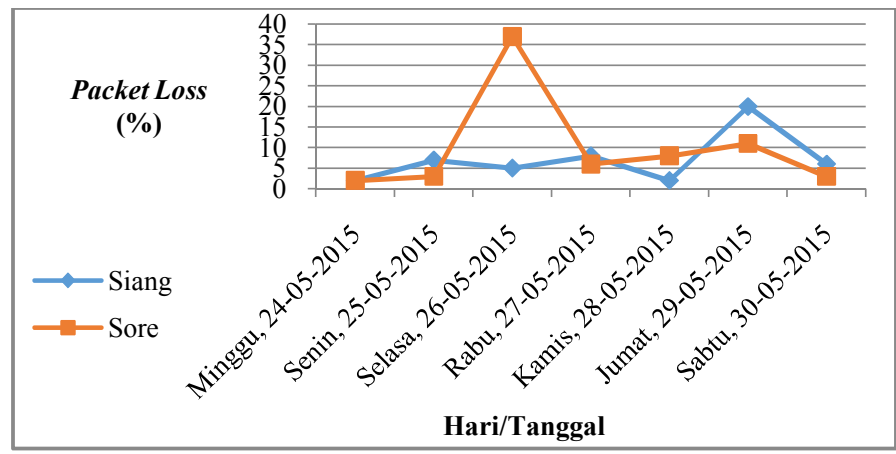

Gambar 18 Grafik Hasil Pengukuran Packet loss Minggu III

Berdasarkan Gambar 18, hasil pengukuran packet loss minggu III di Kecamatan Tembalang Kota Semarang diperoleh packet loss yang paling kecil pada saat siang hari dan paling besar pada saat sore hari. Pengukuran packet loss yang dilakukan mulai tanggal 24-05-2015 sampai dengan 30-05- 
2015 diperoleh trafik paling rendah pada hari Minggu tanggal 24-05-2015 dan trafik paling tinggi pada hari Selasa tanggal 26-05-2015. Grafik hasil pengukuran packet loss minggu IV dapat dilihat pada Gambar 19.

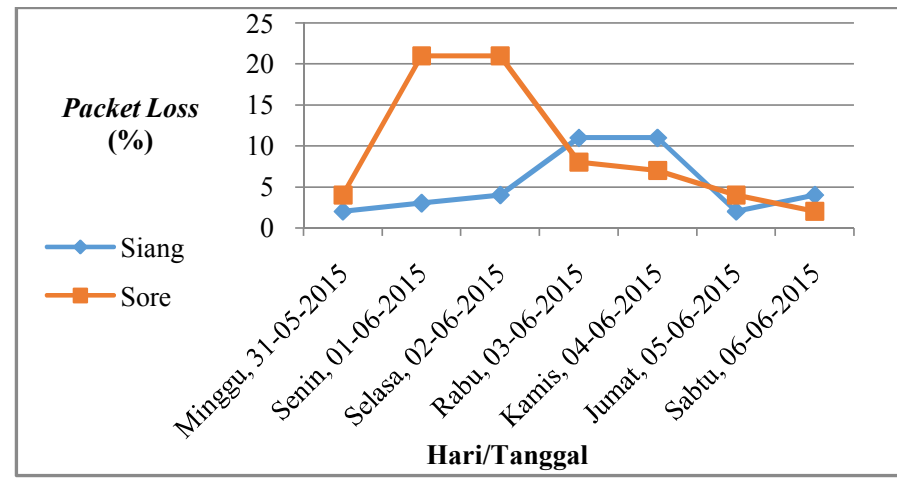

Gambar 19 Grafik Hasil Pengukuran Packet loss Minggu IV

Berdasarkan Gambar 19, hasil pengukuran packet loss minggu IV di Kecamatan Tembalang Kota Semarang diperoleh packet loss yang paling besar pada saat siang hari dan paling kecil pada saat sore hari. Pengukuran packet loss yang dilakukan mulai tanggal 31-05-2015 sampai dengan 06-062015 diperoleh trafik paling rendah pada hari Minggu tanggal 31-05-2015, Jumat tanggal 05-06-2015 dan hari Sabtu tanggal 06-06-2015 dan trafik paling tinggi pada hari Selasa tanggal 02-06-2015. Grafik hasil pengukuran packet loss 1 bulan dapat dilihat pada Gambar 20.

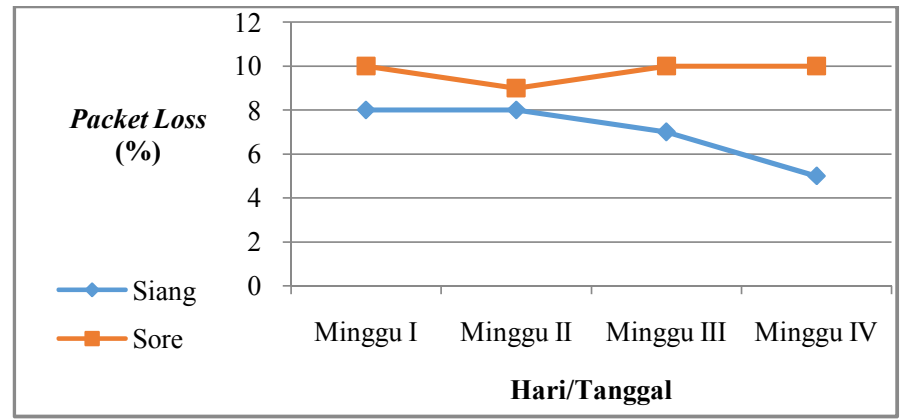

Gambar 20 Grafik Hasil Pengukuran Packet loss1 Bulan

Gambar 20 menunjukkan hasil rekapitulasi pengukuran packet loss dalam hitungan bulan. Berdasarkan rekapitulasi bulanan tersebut, diperoleh kesimpulan hasil pengukuran packet loss yang paling kecil terjadi pada minggu IV. Sedangkan untuk hasil pengukuran packet loss yang paling besar terjadi pada minggu I, II dan III.

Berdasarkan standarisasi TIPHON, untuk kategori degradasi packet loss sangat bagus jika 0-2\%, bagus jika 3$14 \%$, sedang jika $15-24 \%$ dan kategori jelek jika $>25 \%$. Tabel hasil packet loss siang hari di Kecamatan Tembalang dapat dilihat pada Tabel 7 .

Tabel 7 Hasil Packet loss Siang Hari di Kecamatan Tembalang

\begin{tabular}{|c|c|c|c|c|}
\hline Minggu & Sent & $\begin{array}{c}\text { Packets } \\
\text { \%ost }\end{array}$ & TIPHON \\
\hline Minggu I & 10836 & 884 & 8 & Bagus \\
\hline Minggu II & 10622 & 850 & 8 & Bagus \\
\hline Minggu III & 10791 & 780 & 7 & Bagus \\
\hline Minggu IV & 10783 & 556 & 5 & Bagus \\
\hline
\end{tabular}

Tabel hasil packet loss sore hari di Kecamatan Tembalang dapat dilihat pada Tabel 8
Tabel 8 Hasil Packet loss Sore Hari di Kecamatan Tembalang

\begin{tabular}{|c|c|c|c|c|}
\hline Minggu & Sent & $\begin{array}{c}\text { Packets } \\
\text { \%Lost }\end{array}$ & TIPHON \\
\hline Minggu I & 10771 & 1089 & 10 & Bagus \\
\hline Minggu II & 10682 & 958 & 9 & Bagus \\
\hline Minggu III & 10780 & 1083 & 10 & Bagus \\
\hline Minggu IV & 10816 & 1037 & 10 & Bagus \\
\hline
\end{tabular}

Berdasarkan tabel rekapitulasi bulanan tersebut, diperoleh kesimpulan hasil pengukuran packet loss siang dan sore hari termasuk kategori bagus karena besar nilai packet loss antara $3 \%$ sampai $14 \%$.

Berdasarkan hasil pengukuran jaringan telekomunikasi HSDPA di Kecamatan Tembalang Kota Semarang yang dilakukan mulai tanggal 10-05-2015 sampai dengan 06-062015 didapat grafik hasil pengukuran delay minggu I dapat dilihat pada Gambar 21.

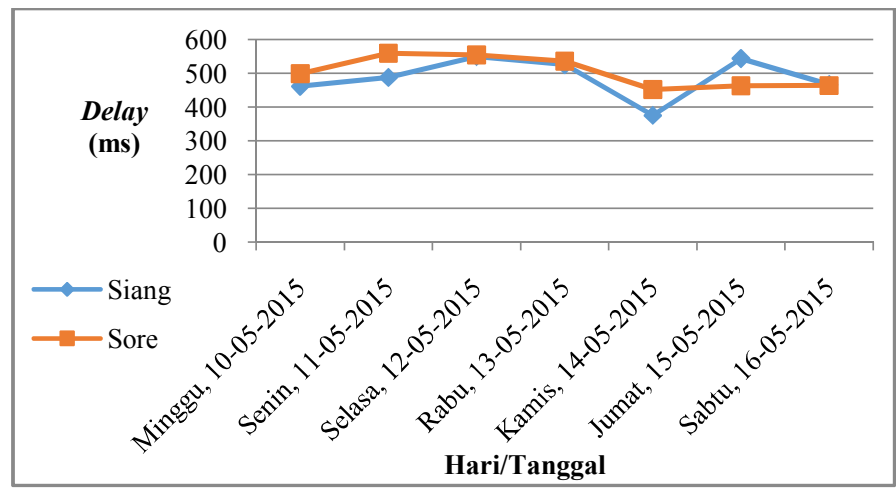

Gambar 21 Grafik Hasil Pengukuran Delay Minggu I

Berdasarkan Gambar 21, hasil pengukuran delay minggu I di Kecamatan Tembalang Kota Semarang diperoleh delay yang paling kecil pada saat siang hari dan paling besar pada saat sore hari. Pengukuran delay yang dilakukan mulai tanggal 1005-2015 sampai dengan 16-05-2015 diperoleh trafik paling rendah pada hari Kamis tanggal 14-05-2015 dan trafik paling tinggi pada hari Selasa tanggal 12-05-2015.Grafik hasil pengukuran parameter delay minggu II dapat dilihat pada Gambar 22.

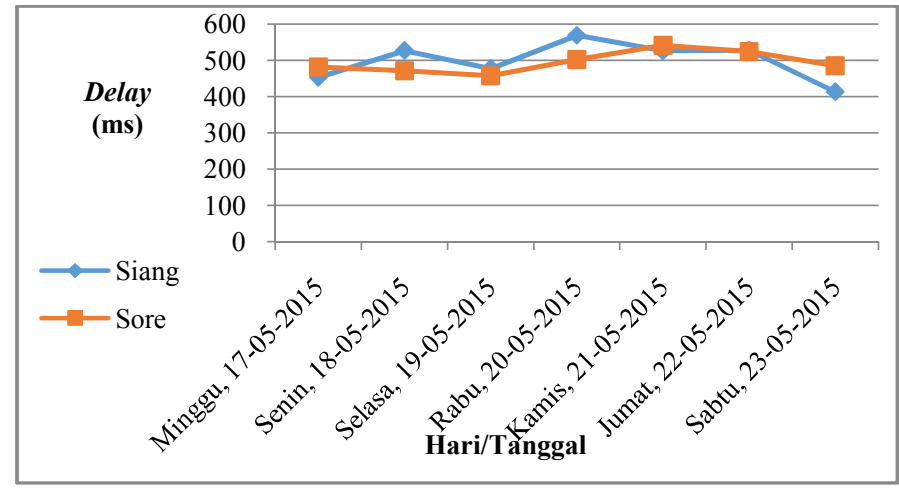

Gambar 22 Grafik Hasil Pengukuran Delay Minggu II

Berdasarkan Gambar 22, hasil pengukuran delay minggu II di Kecamatan Tembalang Kota Semarang diperoleh delay yang paling kecil pada saat siang hari dan paling besar pada saat siang hari. Pengukuran delay yang dilakukan mulai tanggal 1705-2015 sampai dengan 23-05-2015 diperoleh trafik paling rendah pada hari Sabtu tanggal 23-05-2015 dan trafik paling tinggi pada hari Rabu tanggal 20-05-2015. Grafik hasil 
pengukuran parameter delay minggu III dapat dilihat pada Gambar 23.

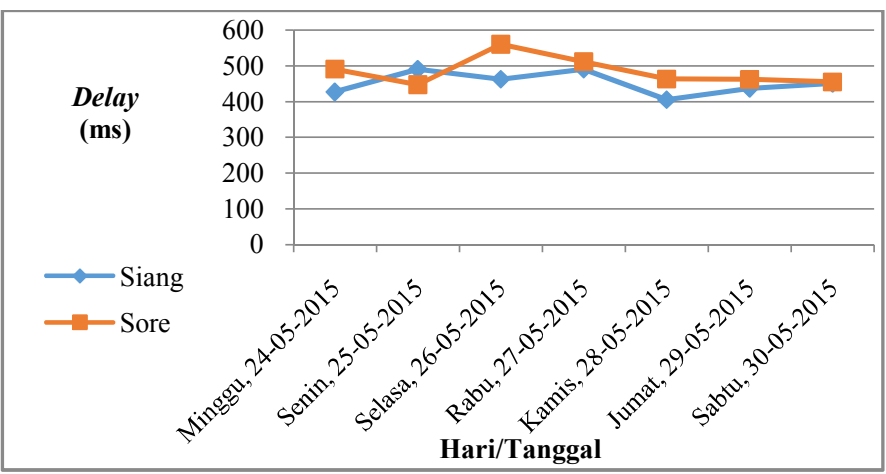

Gambar 23 Grafik Hasil Pengukuran Delay Minggu III

Berdasarkan Gambar 23, hasil pengukuran delay minggu III di Kecamatan Tembalang Kota Semarang diperoleh delay yang paling kecil pada saat siang hari dan paling besar pada saat sore hari. Pengukuran delay yang dilakukan mulai tanggal 24-05-2015 sampai dengan 30-05-2015 diperoleh trafik paling rendah pada hari Kamis tanggal 28-05-2015 dan trafik paling tinggi pada hari Selasa tanggal 26-05-2015. Grafik hasil pengukuran parameter delay minggu IV dapat dilihat pada Gambar 24.

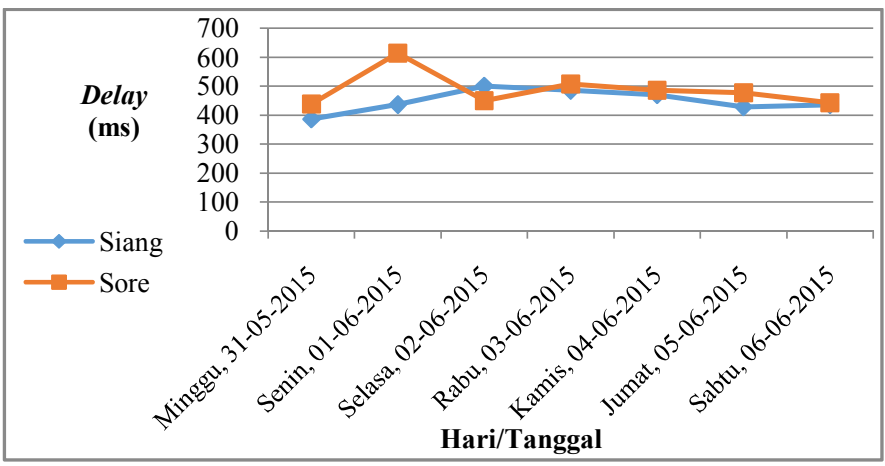

Gambar 24 Grafik Hasil Pengukuran Delay Minggu IV

Berdasarkan Gambar 24, hasil pengukuran delay minggu IV di Kecamatan Tembalang Kota Semarang diperoleh delay yang paling kecil pada saat siang hari dan paling besar pada saat sore hari. Pengukuran delay yang dilakukan mulai tanggal 24-05-2015 sampai dengan 30-05-2015 diperoleh trafik paling rendah pada hari Minggu tanggal 31-05-2015, hari Sabtu tanggal 06-06-2015 dan trafik paling tinggi pada hari Senin tanggal 01-06-2015. Grafik hasil pengukuran parameter delay 1 bulan dapat dilihat pada Gambar 25.

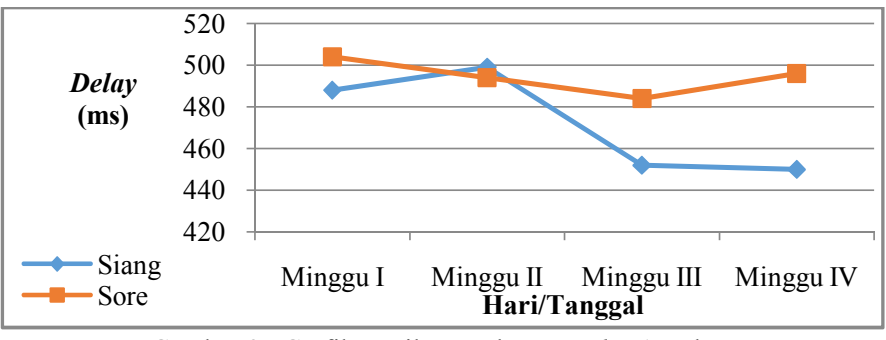

Gambar 25 Grafik Hasil Pengukuran Delay 1 Bulan

Gambar 25 menunjukkan hasil rekapitulasi pengukuran delay dalam hitungan bulan. Berdasarkan rekapitulasi bulanan tersebut, diperoleh kesimpulan hasil pengukuran delay yang paling kecil terjadi pada minggu III. Sedangkan untuk hasil pengukuran delay yang paling besar terjadi pada minggu II.
Berdasarkan standarisasi TIPHON, untuk kategori degradasi delay sangat bagus jika $<150 \mathrm{~ms}$, bagus jika $150 \mathrm{~ms}$ s/d $300 \mathrm{~ms}$, sedang jika $300 \mathrm{~ms}$ s/d $450 \mathrm{~ms}$ dan kategori jelek jika $>450 \mathrm{~ms}$. Tabel hasil delay siang hari di Kecamatan Tembalang dapat dilihat pada Tabel 9.

Tabel 9 Hasil Delay Siang Hari di Kecamatan Tembalang

\begin{tabular}{|c|c|c|c|c|}
\hline \multirow{2}{*}{ Minggu } & \multicolumn{3}{|c|}{ Response Time (ms) } & \multirow{2}{*}{ TIPHON } \\
\hline & Min & Max & Avg & \\
\hline Minggu I & 390 & 996 & 488 & Jelek \\
\hline Minggu II & 403 & 997 & 499 & Jelek \\
\hline Minggu III & 364 & 997 & 452 & Jelek \\
\hline Minggu IV & 355 & 993 & 450 & Sedang \\
\hline
\end{tabular}

Tabel 9 menunjukan hasil rekapitulasi pengukuran delay siang hari dalam hitungan bulan. Berdasarkan rekapitulasi bulanan tersebut, diperoleh kesimpulan hasil pengukuran delay siang hari minggu I, II dan minggu III termasuk kategori jelek karena besar nilai delay $>450 \mathrm{~ms}$. Sedangkan hasil pengukuran delay siang hari minggu IV termasuk kategori sedang karena besar nilai delay antara $300 \mathrm{~ms} \mathrm{~s} / \mathrm{d} 450 \mathrm{~ms}$. Tabel hasil delay sore hari di Kecamatan Tembalang dapat dilihat pada Tabel 10.

Tabel 10 Hasil Delay Sore Hari di Kecamatan Tembalang

\begin{tabular}{|c|c|c|c|c|}
\hline \multirow{2}{*}{ Minggu } & \multicolumn{3}{|c|}{ Response Time (ms) } & \multirow{2}{*}{ TIPHON } \\
\hline & Min & Max & Avg & \\
\hline Minggu I & 389 & 1000 & 504 & Jelek \\
\hline Minggu II & 390 & 998 & 494 & Jelek \\
\hline Minggu III & 338 & 999 & 484 & Jelek \\
\hline Minggu IV & 385 & 1000 & 496 & Jelek \\
\hline
\end{tabular}

Berdasarkan tabel rekapitulasi bulanan tersebut, diperoleh kesimpulan hasil pengukuran delay sore hari termasuk kategori jelek karena besar nilai delay $>450 \mathrm{~ms}$.

Berdasarkan hasil pengukuran QoS HSDPA dengan server lokal (Indonesia) dilakukan pada minggu IV yakni mulai tanggal 20 September 2015 sampai dengan 26 September 2015. Sedangkan penelitian QoS dengan server luar (Polandia) dilakukan pada minggu IV yakni mulai tanggal 31 Mei 2015 sampai dengan 6 Juni 2015 di Kecamatan Tembalang Kota Semarang.

Berdasarkan teori, HSDPA mendukung kecepatan downlink sebesar 1.8 Mbps, 3.6 Mbps, 7.2 Mbps dan 14.4 Mbps. Tabel hasil bandwidth minggu IV di Kecamatan Tembalang dapat dilihat pada Tabel 4.11.

Tabel 4.11 Hasil Bandwidth Minggu IV di Kecamatan Tembalang

\begin{tabular}{|l|c|c|}
\hline \multicolumn{1}{|c|}{ Minggu } & Siang $\begin{array}{c}\text { Bandwidth (kbps) } \\
\text { Sore }\end{array}$ \\
\hline \multicolumn{3}{|c|}{ Server Lokal (Indonesia) } \\
\hline Minggu IV & 2476 & 1925 \\
\hline \multicolumn{3}{|c|}{ Server Luar (Polandia) } \\
\hline Minggu IV & 2381 & 1531 \\
\hline
\end{tabular}

Tabel 4.11 menunjukkan hasil rekapitulasi pengukuran bandwidth dalam hitungan minggu. Berdasarkan teori tersebut dan rekapitulasi minggu IV yang ada diperoleh hasil pengukuran bandwidth server lokal pada siang dan sore hari sudah mendukung kecepatan downlink HSDPA, yakni sebesar 2.4 Mbps untuk siang hari dan 1.9 Mbps untuk sore hari.

Hasil pengukuran bandwidth server luar yang didapat pada siang hari untuk minggu IV sudah mendukung kecepatan downlink HSDPA karena besar nilai bandwidth adalah 2.3 
Mbps. Sedangkan hasil pengukuran bandwidth pada sore hari belum mendukung kecepatan downlink HSDPA karena besar nilai bandwidth adalah $1.49 \mathrm{Mbps}$.

Berdasarkan standarisasi TIPHON, untuk kategori throughput terbaik jika $>2.1 \mathrm{Mbps}$, lebih baik jika $1200 \mathrm{kbps}-$ 2.1 Mbps, baik jika 700-1200 kbps, cukup baik jika 338-700 kbps dan kategori buruk jika 0-338 kbps. Tabel hasil throughput minggu IVdi Kecamatan Tembalang dapat dilihat pada Tabel 4.12 .

Tabel 4.12 Hasil Throughput Minggu IV di Kecamatan Tembalang

\begin{tabular}{|c|c|c|c|}
\hline Waktu & $\begin{array}{c}\text { Rata-rata } \\
\text { Throughput } \\
\text { (bps) }\end{array}$ & $\begin{array}{c}\text { Rata-rata } \\
\text { Throughput } \\
\text { (kbps) }\end{array}$ & TIPHON \\
\hline \multicolumn{4}{|c|}{ Server Lokal (Indonesia) } \\
\hline Siang & 2535366 & 2476 & Terbaik \\
\hline Sore & 1960767 & 1915 & Lebih Baik \\
\hline \multicolumn{5}{|c|}{ Server Luar (Polandia) } \\
\hline Siang & 2437833.9 & 2381 & Terbaik \\
\hline Sore & 156819.56 & 1531 & Lebih Baik \\
\hline
\end{tabular}

Tabel 4.12 menunjukkan hasil rekapitulasi pengukuran throughput siang dan sore hari dalam hitungan minggu. Berdasarkan rekapitulasi mingguan tersebut, diperoleh kesimpulan hasil pengukuran throughput server lokal dan luar pada siang hari minggu IV termasuk kategori terbaik karena besar nilai throughput $>2.1 \mathrm{Mbps}$. Sedangkan hasil pengukuran throughput server lokal dan luar pada sore hari minggu IV termasuk kategori lebih baik karena besar nilai throughput antara $1200 \mathrm{kbps}$ sampai 2.1 Mbps.

Berdasarkan standarisasi TIPHON, untuk kategori degradasi packet loss sangat bagus jika 0-2\%, bagus jika 3$14 \%$, sedang jika $15-24 \%$ dan kategori jelek jika $>25 \%$. Tabel hasil packet loss minggu IV di Kecamatan Tembalang dapat dilihat pada Tabel 4.13.

Tabel 4.13 Hasil Packet Loss Minggu IV di Kecamatan Tembalang

\begin{tabular}{|c|c|c|c|c|}
\hline Waktu & Sent $\begin{array}{c}\text { Packets } \\
\text { Lost }\end{array}$ \%Lost & TIPHON \\
\hline \multicolumn{5}{c|}{ Server Lokal (Indonesia) } \\
\hline Siang & 10777 & 786 & 7 & Bagus \\
\hline Sore & 10765 & 1294 & 12 & Bagus \\
\hline \multicolumn{6}{|c|}{ Server Luar (Polandia) } \\
\hline Siang & 10783 & 556 & 5 & Bagus \\
\hline Sore & 10816 & 1037 & 10 & Bagus \\
\hline
\end{tabular}

Tabel 4.13 menunjukkan hasil rekapitulasi pengukuran packet loss siang dan sore hari dalam hitungan minggu. Berdasarkan rekapitulasi mingguan tersebut, diperoleh kesimpulan hasil pengukuran throughput server lokal dan luar pada siang dan sore hari minggu IV termasuk kategori bagus karena besar nilai packet loss antara 3\% sampai 14\%.

Berdasarkan standarisasi TIPHON, untuk kategori degradasi delay sangat bagus jika $<150 \mathrm{~ms}$, bagus jika $150 \mathrm{~ms}$ s/d 300 ms, sedang jika $300 \mathrm{~ms} \mathrm{~s} / \mathrm{d} 450 \mathrm{~ms}$ dan kategori jelek jika $>450 \mathrm{~ms}$. Tabel hasil delay minggu IV di Kecamatan Tembalang dapat dilihat pada Tabel 4.14.

Tabel 4.14 Hasil Delay Minggu IV di Kecamatan Tembalang

\begin{tabular}{|c|c|c|c|c|}
\hline \multirow{2}{*}{ Waktu } & \multicolumn{7}{|c|}{ Response Time (ms) } & \multirow{2}{*}{ TIPHON } \\
& Min & Max Avg & \\
\hline Server Lokal (Indonesia) \\
\hline Siang & 113 & 999 & 214 & Bagus \\
\hline Sore & 111 & 999 & 215 & Bagus \\
\hline Siang & 355 & 993 & 450 & Sedang \\
\hline Sore & 385 & 1000 & 496 & Jelek \\
\hline
\end{tabular}

Tabel 4.14 menunjukkan hasil rekapitulasi pengukuran throughput siang dan sore hari dalam hitungan minggu. Berdasarkan rekapitulasi mingguan tersebut, diperoleh kesimpulan hasil pengukuran delay server lokal pada siang dan sore hari minggu IV termasuk kategori bagus karena besar nilai delay antara $150 \mathrm{~ms} \mathrm{~s} / \mathrm{d} 300 \mathrm{~ms}$. Hasil pengukuran delay server luar pada siang hari minggu IV termasuk kategori sedang karena besar nilai delay antara $300 \mathrm{~ms}$ s/d $450 \mathrm{~ms}$. Sedangkan pada sore hari minggu IV termasuk kategori jelek karena besar nilai delay $>450 \mathrm{~ms}$.

\section{KESIMPULAN DAN SARAN}

Kesimpulan dari penelitian tugas akhir ini adalah sebagai berikut:

1. Berdasarkan report harian dari tanggal 10-05-2015 sampai dengan 06-06-2015 diperoleh kecenderungan trafik bandwidth dan throughput yang paling besar terjadi pada siang hari dan paling kecil pada sore hari. Sedangkan trafik packet loss dan delay yang paling kecil terjadi pada siang hari dan paling besar pada sore hari.

2. Berdasarkan report mingguan dari tanggal 10-05-2015 sampai dengan 06-06-2015 diperoleh kecenderungan trafik bandwidth dan throughput yang paling tinggi terjadi pada hari Sabtu dan paling rendah pada hari Selasa. Sedangkan trafik packet loss dan delay yang paling rendah terjadi pada hari Sabtu, hari Minggu dan paling tinggi pada hari Selasa.

3. Berdasarkan report bulanan dari tanggal 10-05-2015 sampai dengan 06-06-2015 diperoleh kecenderungan trafik bandwidth dan throughput yang paling besar terjadi pada minggu III dan paling kecil pada minggu I. Sedangkan trafik packet loss dan delay yang paling kecil terjadi pada minggu III, IV dan paling besar pada minggu II.

4. Berdasarkan teori, HSDPA mendukung kecepatan downlink sebesar 1.8 Mbps, 3.6 Mbps, 7.2 Mbps dan 14.4 Mbps. Berdasarkan teori tersebut dan rekapitulasi bulanan yang ada diperoleh kecenderungan hasil pengukuran bandwidth sudah mendukung kecepatan downlink HSDPA, yaitu sebesar 1.8 Mbps sampai dengan 2.5 Mbps.

5. Berdasarkan teori tersebut dan rekapitulasi minggu IV diperoleh kecenderungan hasil pengukuran bandwidth server lokal dan luar sudah mendukung kecepatan downlink HSDPA, yaitu sebesar 1.8 Mbps sampai dengan 2.2 Mbps untuk server lokal dan 1.8 Mbps sampai dengan 1.9 Mbps untuk server luar.

6. Berdasarkan standarisasi TIPHON, untuk kategori throughput terbaik jika $>2.1$ Mbps, lebih baik jika 1200 kbps-2.1 Mbps, baik jika 700-1200 kbps, cukup baik jika 338-700 kbps dan kategori buruk jika 0-338 kbps. Berdasarkan standarisasi tersebut dan rekapitulasi bulanan yang ada diperoleh kecenderungan hasil pengukuran throughput termasuk kategori lebih baik karena besar nilai throughput antara $1200 \mathrm{kbps}-2.1 \mathrm{Mbps}$.

7. Berdasarkan standarisasi tersebut dan rekapitulasi Minggu IV diperoleh kecenderungan hasil pengukuran throughput server lokal termasuk kategori terbaik karena besar nilai throughput $>2.1$ Mbps. Sedangkan hasil pengukuran throughput server luar termasuk kategori lebih baik karena besar nilai throughput antara $1200 \mathrm{kbps}$ sampai 2.1 Mbps.

8. Berdasarkan standarisasi TIPHON, untuk kategori degradasi packet loss sangat bagus jika 0-2\%, bagus jika 3$14 \%$, sedang jika $15-24 \%$ dan kategori jelek jika $>25 \%$. Berdasarkan standarisasi tersebut dan rekapitulasi bulanan yang ada diperoleh kecenderungan hasil pengukuran packet loss termasuk kategori bagus karena besar nilai packet loss antara 3\% sampai $14 \%$. 
9. Berdasarkan standarisasi tersebut dan rekapitulasi minggu IV diperoleh kecenderungan hasil pengukuran packet loss server lokal dan luar termasuk kategori bagus karena besar nilai packet loss antara 3\% sampai 14\%.

10. Berdasarkan standarisasi TIPHON, untuk kategori degradasi delay sangat bagus jika $<150 \mathrm{~ms}$, bagus jika 150 ms s/d 300 ms, sedang jika $300 \mathrm{~ms} \mathrm{~s} / \mathrm{d} 450 \mathrm{~ms}$ dan kategori jelek jika $>450 \mathrm{~ms}$. Berdasarkan teori tersebut dan rekapitulasi bulanan yang ada diperoleh kecenderungan hasil pengukuran delay termasuk kategori jelek karena besar nilai delay $>450 \mathrm{~ms}$.

11. Berdasarkan teori tersebut dan rekapitulasi minggu IV diperoleh kecenderungan hasil pengukuran delay server lokal termasuk kategori bagus karena besar nilai delay antara $150 \mathrm{~ms}$ s/d $300 \mathrm{~ms}$. Sedangkan hasil pengukuran delay server luar termasuk kategori jelek karena besar nilai delay $>450 \mathrm{~ms}$.

Terdapat beberapa saran dari hasil penelitian yaitu sebagai berikut :

1. Pengujian seharusnya menggunakan ID BTS, lokasi yang sama dan variasi jarak untuk mengukur pengaruh jarak agar hasil penelitian tentang analisis QoS jaringan telekomunikasi HSDPA pada teknologi $3.5 \mathrm{G}$ menjadi lebih akurat.

2. Mean Opinion Source dan Post Dial Delay dapat digunakan sebagai parameter QoS lain agar penelitian tentang analisis QoS jaringan telekomunikasi HSDPA pada teknologi 3.5G menjadi lebih akurat.

3. Pengamatan terhadap faktor pendukung dan penghambat dalam analisis QoS jaringan telekomunikasi HSDPA dapat dilakukan agar penyebab kualitas jaringan HSDPA bagus dan jelek dapat diketahui.

\section{DAFTAR PUSTAKA}

[1] Akhmadi, Mukhlisin Ali, Perencaan Jaringan HSDPA Outdoor pada Daerah Urban Menggunakan Aplikasi GENEX U-Net, Makalah Seminar Tugas Akhir Jurusan Teknik Elektro, Universitas Diponegoro Semarang, 2011.

[2] Astriana, Ayu Ananda, Analisis Pengaruh Rain Fading Terhadap Kualitas Layanan High Speed Downlink Packet Access (HSDPA) pada Penggunaan Video Conference, Publikasi Jurnal Skripsi Jurusan Teknik Elektro, Universitas Brawijaya Malang, 2013.

[3] Budianto, Bambang, Analisis Pengaruh Interferensi Terhadap Kapasitas Sel Pada Sistem WCDMA, Skripsi Program Studi Teknik Elektro, Universitas Indonesia Depok, 2009.

[4] Ginano, Marvan, Analisa Performa Kualitas Jaringan VSAT Mobil Pusat Layanan Internet Kecamatan Selawesi Utara, E-journal Teknik Elektro dan Komputer, UNSRAT Manado, 2015.

[5] Holma, Harri., Toskala, Antti., HSDPA/HSUPA for UMTS : High Speed Radio Access for Mobile Communications, John Wiley \& Sons, Ltd, England, 2006.

[6] Irawan, Andika, Analisis Teknis Kualitas Layanan Jaringan Internet Berbasis HSDPA Indosat IM2 Wilavah Maguwoharjo Depok Sleman, Naskah Publikasi Jurusan Teknik Infomatika, AMIKOM Yogyakarta, 2001.

[7] Irhamsyah, Muhammad., Febriani, Putri Rizky., Studi Perbandingan HSDPA pada Telkomsel Flash dan IndosatM2 di Kota Banda Aceh, Jurnal Rekayasa Elektrika - Vol. 9, No. 2, Oktober, 2010.

[8] Moleong, Lexy J., Metodologi Penelitian Kualitatif, Remaja Rosdakarya, Bandung, 2007.

[9] Oktaviani, Perkembangan Teknologi Komunikasi, Jurnal Universitas Gunadarma, 2009.

[10] Peraturan Walikota Semarang No. 18 tentang Rencana Kerja Pembangunan Daerah (RKPD) Kota Semarang Tahun 2015.

[11] Permana, Fanny Nurindra., Affandi, Achmad., Rahardjo, Djoko Suprajitno., Analisa Kinerja MPEG-4 Video Streaming pada Jaringan HSDPA, Jurnal Teknik POMITS - Vol.1, No.1, hal 1-6, 2012.
[12] Santoso, Gatot, Teknik Telekomunikasi, Graha Ilmu, Yogyakarta, 2002.

[13] Sasmita, Wahyu Patrya, Analisis Quality of Service (QoS) pada Jaringan Internet (Studi Kasus : Fakultas Kedokteran Universitas Tanjungpura), Jurnal Program Studi Teknik Informatika Universitas Tanjungpura Pontianak - Vol.1, No.1, 2013.

[14] Simanjuntak, Mei Fenny Wati, Konfigurasi Core Network pada $3 G$ di PT. Indosat Tbk. Region North Sumatera, Makalah Kerja Praktek Program Studi Sistem Komputer, Universitas Diponegoro Semarang, 2014.

[15] Sitepu, Elva Apulina, Analisa Performansi High Speed Downlink Packet Access (HSDPA) pada Node B ITB, Tugas Akhir Jurusan Teknik Telekomunikasi, Institiut Teknologi Telekomunikasi Bandung, 2010.

[16] Sugiyono, Metode Penelitian Kuantitatif, Kualitatif dan $R \& D$, Cetakan ke VIII November 2009, Alfabeta, Bandung.

[17] Stiawansyah, Agus, Analisa Kinerja Jaringan Pusat Internet Pedesaan Berbasis VSAT di Kabupaten Muara Enim, Skripsi Program Studi Teknik Informatika, Universitas Bina Darma Palembang, 2012.

[18] Susandi, Herman., Pinem, Maksum., Analisis Kualitas Layanan Data pada Jaringan Telekomunikasi Berbasis CDMA EVDO Rev.A, SINGUDA ENSIKOM - Vol.6, No.2, 2014.

[19] Tiphon, Telecommunications and Internet Protocol Harmonization Over Networks (TIPHON) General Aspects of Quality of Service (QoS), DTR/ TIPHON-05006, 1999.

[20] Yonathan, Bryan., Bandung, Yoanes., Langi, Armein Z.R., Analisis Kualitas Layanan (QoS) Audio-Video Layanan Kelas Virtual di Jaringan Digital Learning Pedesaan, Konferensi Teknologi Informasi dan Komunikasi untuk Indonesia, Bandung, 2011. 